\title{
Quality characteristics, antioxidant activities and acrylamide formation in cookies added with onion peel powder
}

\author{
Mi-Sook Yeom ${ }^{1}$, Eun-Sun Hwang ${ }^{1,2 *}$ \\ ${ }^{1}$ Department of Human Ecology, Major in Nutrition and Culinary Science, Hankyong National University, \\ Anseong 17579, Korea \\ ${ }^{2}$ School of Wellness Industry Convergence, Major in Food and Nutrition, Hankyong National University, \\ Anseong 17579, Korea
}

\section{양파껍질 분말의 첨가가 쿠키의 품질 특성, 항산화 활성 및 아크릴아마이드 형성에 미치는 영향}

\author{
염미숙 ${ }^{1} \cdot$ 황은선 $^{1,2 *}$ \\ ${ }^{1}$ 한경대학교 생활과학과 영양조리과학전공, ${ }^{2}$ 한경대학교 웰니스산업융합학부 식품영양학전공
}

\begin{abstract}
This study was conducted to investigate the quality characteristics, antioxidant activities and levels of acrylamide formation in cookies containing different amounts of onion peel powder. Onion peel powder was incorporated into the cookies at a level of $2-6 \%$ based on the total weight of wheat flour. The contents of moisture, ash, crude protein, total polyphenols, total flavonoids, and acrylamide content of cookies were determined, in addition to their antioxidant activities, $\mathrm{pH}$ values, loss rates, spread ratios, color, and texture. Upon increasing the amount of onion peel powder, the moisture and ash contents of the cookies increased, wheareas the $\mathrm{pH}$, loss rate and spread ratio of the cookies decreased. In terms of the chromatic analysis, the $L$ and $b$ values decreased, while the a values increased as the amount of added onion peel powder increased. Furthermore, the total polyphenol and total flavonoid contents increased, while the antioxidant activities were significantly higher than that of the control, increasing proportionally with the concentration of onion peel powder. Moreover, the acrylamide contents of the cookies decreased slightly upon increasing the amount of added onion peel powder, with $6 \%$ onion peel powder being particularly effective in inhibiting acrylamide formation. These results suggest that the addition of onion peel powder to cookies will increase the value of cookies by enhancing their antioxidant activities and decreasing acrylamide formation.
\end{abstract}

Key words : onion peel powder, cookie, quality, antioxidant, acrylamide

서 론

양파(Allium cepa L.)는 전 세계적으로 널리 섭취되는 작물로서 우리 식단에도 빠지지 않는 향신 채소이다. 양파 에는 allyl sulfide, allyl propyl disulfide와 같은 황화합물과 quercetin, quercetrin, kaempferol, rutin 등의 flavonoid 계통
의 항산화 물질 및 무기질, 식이섬유, 비타민 $\mathrm{C}$ 가 풍부하 며, 다양한 약리 효과를 지닌 것으로 보고되고 있다(Fossen 등, 1998; Pino 등, 2015).

양파는 항암, 항당뇨, 항콜레스테롤, 항균, 항염증, 항진 균, 항산화 작용과 혈압을 떨어뜨리고, 골다공증을 예방한 다(Lee 등, 2008; Sharma 등, 2014). 또한 양파의 flavonoid

*Corresponding author. E-mail : ehwang@hknu.ac.kr, Phone : +82-31-670-5182, Fax : +82-31-670-5189

Received 17 December 2019; Revised 12 January 2020; Accepted 28 January 2020.

Copyright (C) The Korean Society of Food Preservation.

This is an Open Access article distributed under the terms of the Creative Commons Attribution Non-Commercial License (http://creativecommons.org/licenses/by-nc/4.0) which permits unrestricted non-commercial use, distribution, and reproduction in any medium, provided the original work is properly cited. 
성분 중 하나인 quercetin은 알레르기, 천식, 암, 심장병, 통풍에 매우 효과가 크고, 치매와 같은 대뇌피질을 침범하 는 퇴행성질환, 당뇨합병증에도 효과가 있다(Ko 등, 2015; Nile 등, 2017). 양파껍질은 양파 속에 비해 flavonoid 함량 이 높은데, 약 $80 \%$ 가 quercetin 배당체로 존재한다(Park, 2009). Quercetin 함량은 양파의 안쪽보다 껍질 쪽으로 갈 수록 함량이 증가하는데, 껍질 부위가 중심부보다 10-60 배 높고, 자색 양파가 황색 양파보다 항산화 물질의 함량 이 많은 것으로 알려져 있다(Park, 2009; Zhang 등, 2016). 양파의 생산량은 2017년부터 해마다 꾸준히 증가하여 2019년 생산량은 1,594,450 ton에 이르고 있으나(KOSIS, 2019), 활용은 양파 육질부의 생식이나 단순가공품이 대 부분이어서 폐기되는 양파껍질의 양이 큰 폭으로 증가하 고 있다. 따라서 양파껍질을 활용한 다양한 가공식품의 개발이 더욱 필요한 시점이다. 지금까지 양파껍질을 식품 에 이용한 연구로는, 육류에 첨가하여 지방 산패와 미생물 생육을 억제한 연구(Jung과 Sim, 2019), 막걸리의 항산화 능(Ma 등, 2019), 발효유의 항산화능(Song 등, 2013) 등에 관한 연구가 있다.

식생활 패턴의 변화로 제과·제빵의 수요가 크게 증가 했다(Choi, 2018). 간편하게 먹을 수 있고, 다양한 종류가 개발되어 선택의 폭이 넓어지면서 앞으로도 계속 증가할 것으로 보인다. 그런데 과자는 높은 지방함량으로 인해 저장 중 지질 과산화 문제를 안고 있다(Reddy 등, 2005). 지질 과산화는 과자의 풍미를 해치고 색깔, 영양가를 떨어 뜨리고 유해물질을 쌓이게 한다(Mildner 등, 2009).

이러한 문제점을 해결하기 위해서 항산화 성분이 함유 된 벌나무잎(Park 등, 2018), 모링가잎(Choi, 2018), 자색 당근(Cho와 Chung, 2019), 건오디박(Jeon 등, 2013), 세발 나물(Son 등, 2015), 연잎(Kim 등, 2008) 분말 등을 첨가하 여 과자류의 지질 과산화를 최소화하고, 영양을 강화시키 는 다양한 연구가 시도되고 있다. 항산화 물질은 열에 의 한 안정성에 큰 차이를 보이는데, anthocyanin은 $177^{\circ} \mathrm{C}$ 에 서 베이킹한 크래커에서 $68-74 \%$ 나 감소한(Slavin 등, 2013) 반면, $200^{\circ} \mathrm{C}$ 에서 베이킹한 빵 껍질 중의 quercetin은 $94.2 \%$ 가 남아 있었다고 보고되었다(Vogrincic 등, 2010). 따라서 비교적 열에 강한 quercetin이 풍부한 양파껍질을 쿠키에 첨가하는 것은 항산화능 효과를 높일 수 있을 것으 로 기대된다.

탄수화물 함량이 높은 식품은 $120^{\circ} \mathrm{C}$ 이상의 가열 처리 시 아크릴아마이드가 생성되는데, 이를 장기간 섭취하면 발암 가능성이 있는 것으로 보고되고 있다(IARC, 1994). 쿠키 등의 과자류도 고온 열처리 공정을 거치므로 아크릴 아마이드가 형성된다. 열처리 중 생성되는 아크릴아마이 드를 감소시키기 위해 베이킹 온도, 시간, $\mathrm{pH}$ 를 조정하거 나 항산화 물질을 이용한 연구가 진행되고 있다(Salazar
등, 2012; Sung과 Chen, 2017). 그런데 항산화 추출물을 사용한 실험은 서로 상반된 결과들이 보고되고 있다. 천연 flavonoid가 풍부한 대나무잎을 첨가한 포테이토칩에서는 아크릴아마이드 함량이 $76 \%$ 감소된(Zhang 등, 2007) 반면 에, proanthocyanidine이 풍부한 포도씨유 추출물을 이용한 빵 껍질 모델에서는 감소 효과가 거의 없었다(Acar와 Gokmen, 2009).

따라서 본 연구에서는 양파껍질 분말을 첨가하여 쿠키 를 제조했을 때 항산화 활성도와 아크릴 아마이드 형성을 감소시키는 효과가 있는지를 밝히고, 이와 함께 품질 특성 을 분석하여 제한적으로 사용되는 양파껍질을 좀 더 다양 하게 활용할 수 있는 기초 자료를 제공하고자 한다.

\section{재료 및 방법}

\section{실험재료 및 시약}

밀가루 박력분(Samyang Co., Ltd., Seoul, Korea), 양파껍 질분말(Covata Research Institute, Ltd., Hashimoto, Japan) 은 온라인으로 구매하였고, 베이킹파우더(Geonwon Food, Gimpo, Korea), 쇼트닝(Lotte Foods Co., Ltd., Seoul, Korea), 달걀(CJ Freshway, Yongin, Korea), 백설탕(CJ Cheiljedang Co., Ltd., Incheon, Korea)은 시중에서 구입하였다. FolinCiocalteu's phenol reagent, 1,1-diphenyl-2-picrylhydrazyl (DPPH), gallic acid, quercetin과 sodium phosphate monobasic, acrylamide 표준물질(99\%, Sigma-Aldrich Co., St. Louis, MO, USA)과 내부표준물질인 ${ }^{13} \mathrm{C}_{3}$-labeled acrylamide, formic acid는 Sigma-Aldrich Co., 2,2'-azino-bis(3-ethylbenzothiazoline-6-sulfonic acid) diammonium salt(ABTS)는 Fluk(Heidelberg, Germany)에서 구입하였다. 그리고 acetic acid는 Junsei Chemical Co.(Tokyo, Japan)에서, ethyl alcohol (HPLC grade)은 Samchen Pure Chemical Co.(Pyeongtaek, Korea)에서 methanol은 J.T. Baker Chemical Co.(Philipsburg, $\mathrm{NJ}, \mathrm{USA}$ )에서 구입하여 사용하였다.

\section{쿠키의 재료 배합 및 제조}

양파껍질 분말을 첨가하여 제조한 쿠키의 배합비는 Table 1과 같다. 쿠키의 재료 배합비는 김 분말(Lee, 2017)첨 가 쿠키를 참고하여 예비 실험을 통해 정하였다. 밀가루에 대하여 2, 4, 6\% 첨가하여 $\mathrm{OP} 2, \mathrm{OP} 4, \mathrm{OP} 6$ 으로 구분하였다.

쿠키는 $\mathrm{AACC}$ 법(AACC, 2000)에 따라 크림법을 이용하 여 제조하였다. 먼저, 반죽기(BH200, Bread Garden, Seoul, Korea)에 설탕, 쇼트닝을 첨가한 후, 1 단으로 1 분, 3 단으로 30 초, 5 단으로 30 초 순서로 혼합하여 크림화시켰다. 달걀 을 첨가한 후 3 단으로 2 분간 혼합한 후 미리 베이킹파우더 를 섞고 2회 체를 친 밀가루를 가하고, 주걱으로 잘 혼합하 여 쿠키 반죽을 제조하였다. 이후 반죽을 랩에 씨워 냉장 
Table 1. Formula for cookies prepared with different amounts of onion peel powder

\begin{tabular}{crrrr}
\hline Ingredients $(\mathrm{g})$ & \multicolumn{3}{c}{ Group $^{\mathrm{l})}$} & OP6 \\
\cline { 2 - 5 } & Control & OP2 & OP4 & 9 \\
\hline Onion peel powder & 0 & 3 & 6 & 141 \\
Wheat flour & 150 & 147 & 144 & 65 \\
Shortening & 65 & 65 & 65 & 50 \\
Sugar & 50 & 50 & 50 & 34 \\
Egg & 34 & 34 & 34 & 1 \\
Baking powder & 1 & 1 & 1 & 1 \\
\hline
\end{tabular}

${ }^{1)}$ Control, no onion peel powder added; OP2, $2 \%$ onion peel powder added; OP4, 4\% onion peel powder added; OP6, 6\% onion peel powder added.

고(LG, CA-F17DZ, Seoul, Korea)에서 1시간 동안 휴지시 킨 후 밀대로 균일하게 편 다음 쿠키 틀로 찍어 지름 40 $\mathrm{mm}$, 두께 $5 \mathrm{~mm}$ 로 제조하여 철판에 팬닝했다. 오븐(Daeyong BDO 7106, Seoul, Korea)을 이용하여 윗불 $190^{\circ} \mathrm{C}$, 아랫불 $160^{\circ} \mathrm{C}$ 에서 10 분간 구워 상온에서 30 분간 방냉 후 시료로 사용하였다.

\section{일반성분 분석}

양파껍질 분말을 첨가한 쿠키의 수분함량은 시료 $3 \mathrm{~g}$ 을 취하여, $105^{\circ} \mathrm{C}$ 상압가열 건조법으로 시료 당 3 개씩 취하여 측정한 값의 평균을 구하였다. 조회분은 $600^{\circ} \mathrm{C}$ 직접회화 법으로 측정하였다. 조단백질은 Semimicro-Kjeldhal 법으 로 자동 단백질 분석기(Kjeltec 2400 AUT, Foss Tecator, Eden Prairie, MN, USA)로 분석하였다.

\section{쿠키 반죽의 $\mathrm{pH}$ 측정}

양파껍질 분말을 첨가한 반죽의 $\mathrm{pH}$ 를 측정하기 위하여 시료 $5 \mathrm{~g}$ 에 증류수 $45 \mathrm{~mL}$ 를 혼합하고, vortex mixer(Vortex Genie 2, Scientific Industries Inc., Bohemia, NY, USA)로 교반하였다. 이후 여과지(Whatman No.2, GE Healthcare Co., Shanghai, China)로 여과한 여액을 $\mathrm{pH} \operatorname{meter}(420$ Benchtop, Orion Research, Beverly, MA, USA)로 $\mathrm{pH}$ 를 측정 하였다.

\section{쿠키의 퍼짐성 및 손실률 측정}

쿠키의 퍼짐성 지수(spread factor)는 AACC법(AACC, 2000)에 따라 측정하였다. 즉, 쿠키의 직경은 가로로 정렬한 쿠키 6 개의 길이를 측정한 후, 다시 $90^{\circ} \mathrm{C}$ 로 회전시켜 측정하 였다. 쿠키의 두께는 쿠키 6 개를 쌓은 높이를 측정한 후 쌓은 순서를 바꾸어 다시 측정하였다. 이후 측정한 값을 아래의 식으로 산출하였다. 손실률(loss rate)은 굽기 전후
무게를 각각 측정한 후, 아래의 식에 따라 산출하였다.

$$
\text { 쿠키의 퍼짐성 지수 }=\frac{\text { 쿠키 } 6 \text { 개의 평균 직경 }(\mathrm{mm})}{\text { 쿠키 } 6 \text { 개의 평균 두께 }(\mathrm{mm})}
$$$$
\text { 손실률 }(\%)=\frac{\text { 굽기 전후 한 개의 중량 차 }(\mathrm{g})}{\text { 굽기 전 반죽 한 개의 중량 }(\mathrm{g})} \times 100
$$

\section{쿠키의 색도 측정}

양파껍질 분말의 색도는 색차계(Chrome Meter CR-300, Minolta, Tokyo, Japan)를 사용하여 명도(L, lightness), 적색 도(a, redness), 황색도(b, yellowness)값으로 표시하였다. 표준백색 판의 $\mathrm{L}, \mathrm{a}, \mathrm{b}$ 값은 각각 $97.10,+0.24,+1.75$ 였다.

\section{쿠키의 경도 측정}

제조된 쿠키의 기계적 물성측정은 texture analyzer(CT3 $10 \mathrm{~K}$, Brookfield., Middleboro, MA, USA)를 사용하여 texture profile analysis(TPA)로 측정하였다. 양파껍질 함량을 달리 하여 제조한 쿠키는 상온에서 plate의 중앙에 놓고 압착실 험(two-bite test)을 3 회 반복 측정하여 평균값을 구하였다. Pre test는 $2.0 \mathrm{~mm} / \mathrm{s}$, test speed는 $10 \mathrm{~mm} / \mathrm{s}$, Load cell은 10 $\mathrm{kg}$ 으로 설정하였다.

\section{쿠키의 총 polyphenol 및 총 flavonoid 함량 분석}

쿠키의 총 polyphenol 함량은 Singleton과 Rossi(1965) 방 법을 변형하여 측정하였다. 시료 $1 \mathrm{~g}$ 에 $70 \%$ 에탄올을 넣어 $40 \mathrm{~g}$ 으로 정용하고, 실온에서 60 분간 sonification 한 후에 $3,000 \mathrm{rpm}$ 에서 10 분간 원심분리하여 상층액을 얻어 쿠키 추출물로 하였다. 쿠키 추출물 $(0.5 \mathrm{~mL})$ 에 $2 \mathrm{~N}$ FolinCiocalteu's phenol 시약 $0.5 \mathrm{~mL}$ 를 혼합한 뒤 3 분간 실온에 서 반응시킨 후, $2 \% \mathrm{Na}_{2} \mathrm{CO}_{3} 1.5 \mathrm{~mL}$ 를 첨가한 뒤 2시간 
동안 암소에서 반응시켰다. 반응물은 microplate reader (Infinite M200 Pro, Tecan Group Ltd., San Jose, CA, USA)를 이용하여 $760 \mathrm{~nm}$ 에서 흡광도를 측정하였다. 쿠키에 함유 된 총 polyphenol 함량은 gallic acid의 표준곡선(6.25 - 100 $\mu \mathrm{g} / \mathrm{mL})$ 을 이용하여 쿠키 $\mathrm{g}$ 당 gallic acid equivalent $(\mathrm{mg}$ $\mathrm{GAE} / \mathrm{g}$ )으로 표시하였다.

쿠키의 총 flavonoid 함량은 Woisky와 Salatino(1998) 방 법을 변형하여 측정하였다. 쿠키 추출물 $1 \mathrm{~mL}$ 와 $2 \%$ aluminium chloride methanolic solution $1 \mathrm{~mL}$ 를 혼합하여 실온 에서 15 분 동안 반응시켰다. 이후 microplate reader를 이용 하여 $430 \mathrm{~nm}$ 에서 흡광도를 측정하였다. 쿠키에 함유된 총 flavonoid 함량은 quercetin의 표준곡선 $(6.25-100 \mu \mathrm{g} / \mathrm{mL})$ 을 이용하여 쿠키 $\mathrm{g}$ 당 quercetin equivalent $(\mathrm{mg} \mathrm{QE} / \mathrm{g})$ 으로 나타내었다.

\section{쿠키의 항산화 활성 측정}

쿠키의 DPPH 라디칼 소거활성은 Blois(1958)법에 따라 측정하였다. 쿠키 추출물 $100 \mu \mathrm{L}$ 를 96-well plate에 넣고, $0.2 \mathrm{mM} \mathrm{DPPH}$ 용액 $100 \mu \mathrm{L}$ 를 첨가한 후 $37^{\circ} \mathrm{C}$ 에서 30 분간 반응시켰다. Microplate reader를 사용하여 $515 \mathrm{~nm}$ 에서 흡 광도를 측정하였다. 쿠키 추출물의 DPPH 라디칼 소거 활 성은 아래 식에 대입하여 산출하였다.

$\mathrm{DPPH}$ 라디칼 소거활성 $(\%)=$

$$
\frac{1 \text {-시료 첨가구의 흡광도 }}{\text { 시료 무 첨가구의 흡광도 }} \times 100
$$

쿠키의 ABTS 라디칼 소거활성은 $\operatorname{Re}$ 등(1999)법에 따라 측정하였다. 본 실험 전에 $7.0 \mathrm{mM} \mathrm{ABTS}$ 와 $2.45 \mathrm{mM}$ potassium persulfate를 24시간 동안 암소에서 반응시켜 ABTS 양이온을 형성시킨 후 $735 \mathrm{~nm}$ 에서 흡광도 값(OD) 이 $0.17 \pm 0.03$ 이 되도록 에탄올로 희석하여 사용하였다. 쿠 키 추출물 $100 \mu \mathrm{L}$ 를 96-well plate에 넣고, 흡광도를 맞춘 $\mathrm{ABTS}$ 용액 $100 \mu \mathrm{L}$ 를 첨가한 후 $37^{\circ} \mathrm{C}$ 에서 30 분간 반응시 켰다. Microplate reader를 사용하여 $732 \mathrm{~nm}$ 에서 흡광도를 측정하였다. 쿠키 추출물의 ABTS 라디칼 소거 활성은 아 래의 식에 대입하여 산출하였다.

$\mathrm{ABTS}$ 라디칼 소거활성 $(\%)=$

$$
\frac{1-\text { 시료 첨가구의 흡광도 }}{\text { 시료 무 첨가구의 흡광도 }} \times 100
$$

\section{쿠키의 아크릴아마이드 함량 분석}

아크릴아마이드 함량은 FDA 분석법(FDA, 2003)을 변 형하여 측정하였다. LC/MS(liquid chromatography-tandem mass spectrometry)로 $\mathrm{MRM}$ (multiple reaction monitoring)을 사용하였으며, 시약은 모두 HPLC 등급을 사용하였다. 정 제 컬럼은 Oasis $\mathrm{HLB}\left(\mathrm{C}_{18}, 200 \mathrm{mg}, 6 \mathrm{~mL}\right)$, Bond Elut$\operatorname{Accucat}\left(\mathrm{C}_{8}, 200 \mathrm{mg}, 3 \mathrm{~mL}\right)$ 을 사용하였다. 표준원 액은 아 크릴아마이드 표준품을 물에 녹여 $1 \mathrm{mg} / \mathrm{mL}$ 가 되도록 한 후 실험에 필요한 농도로 희석하여 사용하였다. 내부표준 원 액은 탄소 13 동위원소 $\left({ }^{13} \mathrm{C}_{3}\right)$ 로 치환된 아크릴아마이드 를 메탄올에 녹여 $1 \mathrm{mg} / \mathrm{mL}$ 로 만들었고, 여기에 $0.1 \%$ formic acid를 가해 $500 \mathrm{ng} / \mathrm{mL}$ 농도의 내부표준용액을 만 들어 사용하였다. 쿠키 시료는 Fig. 1과 같이 전처리하였 다. 즉, 쿠키 시료를 균질화한 후 $1 \mathrm{~g}$ 을 취하여 $50 \mathrm{~mL}$ 폴리 프로필렌 원심분리용 튜브에 넣고, 내부 표준용액 $1 \mathrm{~mL}$ 와 물 $9 \mathrm{~mL}$ 를 첨가한 후 잘 혼합하여 진탕기에 넣어 300 $\mathrm{rpm}$ 으로 25 분 동안 추출한 후 원심분리기를 이용하여

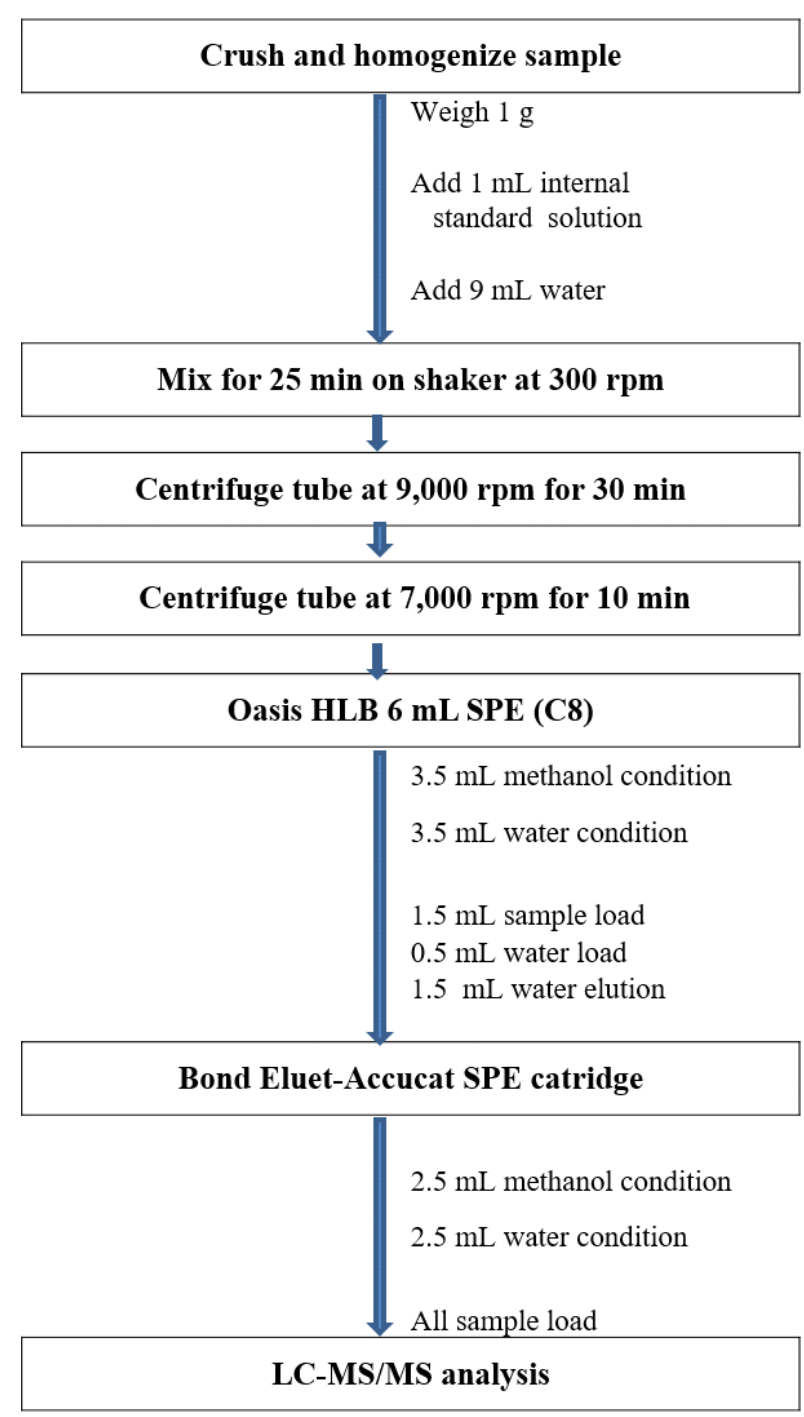

Fig. 1. The scheme for sample preparation of acrylamide analysis. 
$9,000 \mathrm{rpm}$ 으로 30 분 동안 원심분리하였다. 원심분리하여 얻어진 물층 $5 \mathrm{~mL}$ 를 여과튜브에 옮기고 $7,000 \mathrm{rpm}$ 으로 10 분간 다시 원심분리하여 $\mathrm{A}$ 액을 얻었다. 메탄올 $3.5 \mathrm{~mL}$ 와 물 $3.5 \mathrm{~mL}$ 로 활성화시킨 Oasis HLB SPE 카트리지에 $\mathrm{A}$ 액 $1.5 \mathrm{~mL}$ 를 넣어 통과시킨 후 물 $0.5 \mathrm{~mL}$ 를 흘려버리고 물 $1.5 \mathrm{~mL}$ 를 용출시켜 모아 $\mathrm{B}$ 액을 얻었다. 메탄올 $2.5 \mathrm{~mL}$ 와 물 $2.5 \mathrm{~mL}$ 로 활성화시킨 Bond Elut-Accucat SPE 카트리 지에 $\mathrm{B}$ 액 $1.5 \mathrm{~mL}$ 를 넣은 후 처음 $0.5 \mathrm{~mL}$ 를 흘려버리고 이후 얻어진 $1 \mathrm{~mL}$ 를 LC/MS 분석에 사용하였다.

아크릴아마이드는 LC/MS-2020(Shimadzu, Tokyo, Japan), Nexera XR(Shimadzu, Tokyo, Japan)을 이용해 분석하였다. 이동상은 $0.1 \%$ acetic acid와 $0.5 \%$ formic acid가 포함된 수용액으로 하고, MS 이온화 모드는 $\mathrm{HESI}^{+}$로 하였고, 이 온 모니터링은 acrylamide는 $72 \mathrm{~m} / z>55 \mathrm{~m} / z$ 를, ${ }^{13} \mathrm{C}_{3-}$ acrylamides는 $75 \mathrm{~m} / \mathrm{z}>58 \mathrm{~m} / \mathrm{z}$ 으로 확인하였다.

\section{통계분석}

실험 결과는 SPSS 통계 프로그램(ver. 17.0, SPSS Inc., Chicago, IL, USA)을 이용하여 평균과 표준편차를 계산하 였다. 분산분석(ANOVA)을 수행한 후 유의적인 차이가 있는 경우에는 $p<0.05$ 수준에서 Duncan's multiple range test를 실시하였다.

\section{결과 및 고찰}

\section{일반성분 함량}

양파껍질 분말 첨가수준에 따른 쿠키의 수분, 회분 및 단백질 함량은 Table 2 와 같다. 쿠키의 각 군별 수분함량은 대조군이 $2.95 \%$ 이고, 첨가군의 수분함량은 $3.13-3.43 \%$ 로 통계적으로 유의하게 증가하였다. 선행연구에서 벌나 무잎(Park 등, 2018), 모링가잎(Choi, 2018), 흑율피(Son 등, 2017) 분말을 첨가한 쿠키에서 밀가루 대체 부재료를 첨가 한 실험군의 수분함량이 증가하여 본 연구결과와 유사한 경향을 보였다. 수분 결합력이 높을수록 수분함량이 높은
데, 결합된 물은 시료 입자에 흡수되거나 시료 입자의 표 면에 흡수된다(Lee 등, 2000). 본 연구에서 양파껍질 분말 첨가군의 수분함량이 증가한 것은 양파껍질의 높은 식이 섬유함량 때문인 것으로 추정된다(Jaime 등, 2002). 즉, 양 파껍질 첨가량이 증가할수록 반죽 내에 수분 보유력을 지닌 섬유소가 증가함에 따라 수분 결합 능력이 증가하게 되므로 쿠키의 수분함량이 증가한 것으로 판단된다.

조회분은 대조군이 $0.63 \%$ 였고, 양파껍질 분말의 첨가 량이 증가할수록 $0.66-0.79 \%$ 까지 조회분 함량이 통계적 으로 유의성 있게 증가하였다 $(\mathrm{p}<0.05)$. 조단백질은 대조군 이 $8.35 \%$, 실험군이 $8.28-8.32 \%$ 로 실험군에서 다소 감소 하는 경향을 보였으나, 통계적인 차이는 없었다. 양파껍질 분말은 밀가루 대비 회분의 함량은 훨씬 높고, 단백질 함 량은 낮은 것으로 보고되고 있다(Sayed 등, 2014). 본 연구 에서 양파껍질 분말을 첨가한 실험군의 조회분 함량이 유의미하게 증가한 것은 양파껍질 분말의 조회분 함량이 대조군의 밀가루 조회분 함량보다 높았기 때문인 것으로 사료된다.

\section{쿠키 반죽의 $\mathrm{pH}$}

쿠키 반죽의 $\mathrm{pH}$ 측정 결과는 Table 3 과 같다. 양파껍질 분말의 $\mathrm{pH}$ 는 4.32 , 밀가루의 $\mathrm{pH}$ 는 5.62 였다. 양파껍질 분 말을 첨가하지 않은 대조군의 $\mathrm{pH}$ 는 7.09 이었고, 실험군의 $\mathrm{pH}$ 는 6.44-6.83으로 양파껍질 분말 첨가수준이 증가할수 록 통계적으로 유의하게 감소하였다 $(\mathrm{p}<0.001)$. 대조군과 실험군 사이에서 유의한 차이를 보였으며, 실험군 내에서 도 양파껍질 첨가량에 따라서 유의적인 차이를 나타냈다. Chia 등(2018)의 연구에 따르면 양파껍질 추출물에는 caffeic acid, ferulic acid, sinapinic acid, tannic acid, 유기산 이 함유되어 있으며, 이러한 성분들로 인해 양파껍질의 $\mathrm{pH}$ 가 낮은 것으로 보고되었다. 본 연구에서 양파껍질을 첨가한 실험군의 $\mathrm{pH}$ 가 양파껍질을 첨가하지 않은 대조군 의 $\mathrm{pH}$ 보다 낮은 것은, caffeic acid 등 유기산을 함유한 양파껍질의 $\mathrm{pH}$ 가 낮기 때문인 것으로 사료된다. Kim 등

Table 2. Proximate composition composition of cookies with different amounts of onion peel powder

\begin{tabular}{cccccc}
\hline & \multicolumn{3}{c}{ Group $^{1)}$} & OP6 & F-value \\
\cline { 2 - 5 } Measurement (\%) & Control & OP2 & OP4 & $3.43 \pm 0.10^{\mathrm{a}}$ & $7.16^{* 4)}$ \\
\hline Moisture content & $2.95 \pm 0.10^{2) \mathrm{c} 3)}$ & $3.13 \pm 0.19^{\mathrm{bc}}$ & $3.26 \pm 0.09^{\mathrm{ab}}$ & $0.79 \pm 0.03^{\mathrm{a}}$ & $4.25^{*}$ \\
Crude ash & $0.63 \pm 0.07^{\mathrm{b}}$ & $0.66 \pm 0.06^{\mathrm{b}}$ & $0.73 \pm 0.06^{\mathrm{ab}}$ & $8.28 \pm 0.29$ & 0.064 \\
Crude protein & $8.35 \pm 0.19$ & $8.32 \pm 0.22$ & $8.29 \pm 0.19$ & 8.96 \\
\hline
\end{tabular}

\footnotetext{
${ }^{1)}$ Control, no onion peel powder added; OP2, $2 \%$ onion peel powder added; OP4, 4\% onion peel powder added; OP6, 6\% onion peel powder added.

${ }^{2)}$ Values represent the mean $\pm \mathrm{SD}(\mathrm{n}=3)$.

3), a, Different superscripts in a same row indicate significantly different by Duncan's multiple range test $(\mathrm{p}<0.05)$.

4)* $\mathrm{p}<0.05$.
} 
Table 3. pH of cookie dough with different amounts of onion peel powder

\begin{tabular}{|c|c|c|c|c|c|}
\hline \multirow{2}{*}{ Measurement } & \multicolumn{4}{|c|}{ Group $^{1)}$} & \multirow{2}{*}{ F-value } \\
\hline & Control & $\mathrm{OP} 2$ & OP4 & OP6 & \\
\hline $\mathrm{pH}$ & $7.09 \pm 0.05^{2) \mathrm{a} 3)}$ & $6.83 \pm 0.11^{\mathrm{b}}$ & $6.56 \pm 0.07^{\mathrm{c}}$ & $6.44 \pm 0.08^{\mathrm{c}}$ & $37.07^{* * * 4)}$ \\
\hline
\end{tabular}

(2018)에 따르면 프리카 분말 첨가 쿠키 연구에서도 밀가 루의 대체제로 프리카 분말을 첨가하여 쿠키를 제조한 경우, 쿠키 반죽의 $\mathrm{pH}$ 가 감소하였다고 보고하여 본 연구 결과와 유사한 경향을 나타냈다.

\section{쿠키의 퍼짐성 및 손실률}

쿠키의 퍼짐성 지수는 Table 4에 나타내었다. 퍼짐성 지수는 대조군이 6.25이고, 실험군은 5.53-5.97로 양파껍 질 분말 첨가량이 증가함에 따라 유의적으로 감소하였다 $(\mathrm{p}<0.01)$. 퍼짐성은 베이킹 후 반죽의 두께는 얇아지고, 직 경이 증가한 정도를 표시한 것으로, 베이킹 조건, 원료의 특성, 식이섬유 함량, 단백질 함량, 수분 등에 따라 달라진 다. 특히 수분의 상태에 따라 달라지는데, 반죽 내 수분이 자유수의 형태로 존재하면 퍼짐성 지수가 높고, 결합수로 존재하면 퍼짐성 지수는 낮다고 알려져 있다(Choi, 2009). 본 연구에서 양파껍질 분말을 첨가한 쿠키의 퍼짐성이 감소한 것은 양파껍질의 높은 식이섬유 함량(Jaime 등, 2002)에 기인한 것으로 판단된다. 반죽 내 식이섬유 함량 이 높으면, 식이섬유의 수분 보유력으로 인해 당 용해에 필요한 수분을 섬유소가 흡수하게 되어 당의 용해성과 보습성이 감소하게 된다. 이로 인해 반죽의 유동에 필요한 점도를 갖지 못하게 되어 퍼짐성은 감소하게 된다 $(\mathrm{Kim}$ 등, 2018; Jung과 Lee, 2011). 기존 연구에서 자색 당근 분말 을 첨가한 쿠키(Cho와 Chung, 2019), 벌나무잎 분말(Park 등, 2018), 율피 분말(Joo와 Choi, 2012a) 첨가 쿠키에서
밀가루 대체 부재료의 첨가량이 증가할수록 반죽 내 식이 섬유 함량이 증가하여 퍼짐성이 낮아졌다고 보고하여 본 연구결과와 유사한 경향을 보였다. 손실률은 Table 4에 나타낸 바와 같이 대조군이 $13.51 \%$ 이고, 양파껍질 분말 첨가군은 $11.44-12.95 \%$ 의 분포를 보였다. 양파껍질 첨가 량이 증가함에 따라 손실률은 유의적으로 감소하였다 $(\mathrm{p}<0.01)$. 이러한 결과는 양파껍질 첨가량이 증가할수록 식이섬유 함량이 증가함에 따라 수분 보유력이 증가하고, 이로 인해 손실율이 감소한 것으로 사료된다.

\section{쿠키의 색도}

양파껍질 분말 첨가량을 달리하여 제조한 쿠키의 색도 측정 결과는 Table 5 와 같다. 쿠키의 밝은 정도를 나타내 는 L값은 대조군이 76.45 , 실험군이 52.19-58.28로 실험 군의 명도가 더 낮아졌으며, 양파껍질 분말의 첨가량이 증가할수록 명도가 유의적으로 감소하였다 $(\mathrm{p}<0.001)$. 적 색도를 나타내는 a값은 대조군이 0 , 실험군은 6.61-9.13 으로 실험군에서 증가하였으며, 첨가량의 증가에 따라 $\mathrm{a}$ 값도 증가하였다 $(\mathrm{p}<0.001)$. 이것은 첨가된 양파껍질 분 말의 색도에 의해 실험군의 L값은 낮아지고, $\mathrm{a}$ 값은 증가한 것으로 판단된다. 황색도를 나타내는 $\mathrm{b}$ 값은 대조군이 33.03 이었고, 실험군은 26.14-27.72로 대조군이 실험군에 비해 유의적으로 더 높은 값을 나타냈다 $(\mathrm{p}<0.001)$. 선행연 구에서도 쿠키에 건오디박(Jeon 등, 2013)과 크린베리 (Choi와 Lee, 2015)를 첨가하여 쿠키를 제조한 경우, 붉은

Table 4. Spread factor and loss rate of cookies added with different amounts of onion peel powder

\begin{tabular}{|c|c|c|c|c|c|}
\hline \multirow{2}{*}{ Measurement } & \multicolumn{4}{|c|}{ Group $^{1)}$} & \multirow{2}{*}{ F-value } \\
\hline & Control & $\mathrm{OP} 2$ & $\mathrm{OP} 4$ & OP6 & \\
\hline Spread factor & $6.25 \pm 0.05^{2) \mathrm{a} 3)}$ & $5.97 \pm 0.04^{\mathrm{b}}$ & $5.64 \pm 0.03^{\mathrm{c}}$ & $5.53 \pm 0.14^{\mathrm{c}}$ & $47.81^{* * 4)}$ \\
\hline Loss rate $(\%)$ & $13.51 \pm 0.82^{\mathrm{a}}$ & $12.95 \pm 0.40^{\mathrm{a}}$ & $11.50 \pm 0.38^{\mathrm{b}}$ & $11.44 \pm 0.78^{\mathrm{b}}$ & $8.11^{* *}$ \\
\hline
\end{tabular}


Table 5. Hunter's color values of cookies with different amounts of onion peel powder

\begin{tabular}{|c|c|c|c|c|c|}
\hline \multirow{2}{*}{ Measurement $^{1)}$} & \multicolumn{4}{|c|}{ Group $^{2)}$} & \multirow{2}{*}{ F-value } \\
\hline & Control & OP2 & OP4 & OP6 & \\
\hline L-value & $76.45 \pm 1.08^{3) \mathrm{a} 4)}$ & $58.28 \pm 1.26^{\mathrm{b}}$ & $55.79 \pm 0.43^{\mathrm{bc}}$ & $52.19 \pm 0.64^{\mathrm{c}}$ & $415.47^{* * * 5)}$ \\
\hline a-value & $-0.00 \pm 0.26^{\mathrm{c}}$ & $6.61 \pm 0.11^{\mathrm{b}}$ & $8.59 \pm 0.21^{\mathrm{a}}$ & $9.13 \pm 0.15^{\mathrm{a}}$ & $1,384.72^{* * *}$ \\
\hline b-value & $33.03 \pm 0.44^{\mathrm{a}}$ & $27.72 \pm 0.26^{\mathrm{b}}$ & $26.95 \pm 1.14^{\mathrm{b}}$ & $26.14 \pm 0.35^{\mathrm{b}}$ & $68.65^{* * *}$ \\
\hline
\end{tabular}

${ }^{1)}$ L-value: Black=0, White $=100$; a-value: $\mathrm{Red}=0$ to 100 , Green=0 to 80 ; b-value: Yellow $=0$ to $70, \mathrm{Blue}=0$ to 70 .

${ }^{2)}$ Control, no onion peel powder added; OP2, $2 \%$ onion peel powder added; OP4, 4\% onion peel powder added; OP6, 6\% onion peel powder added.

${ }^{3)}$ Values represent the mean $\pm \mathrm{SD}(\mathrm{n}=3)$.

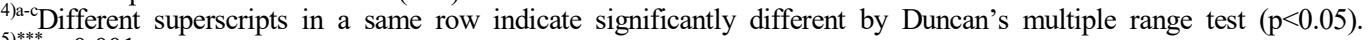

${ }^{5 * * *} \mathrm{p}<0.001$.

색을 띠는 부재료의 첨가량이 증가함에 따라 $\mathrm{L}$ 값과 $\mathrm{b}$ 값은 감소한 반면 $\mathrm{a}$ 값은 증가하는 것으로 나타나, 본 실험결과 와 유사한 경향을 보였다. 일반적으로 쿠키의 표면 색도는 첨가한 부재료나 고온의 열처리 중 재료에 함유된 당분에 의한 캐러멜화 반응에 따라 달라진다(Park 등, 2005).

\section{쿠키의 경도}

양파껍질 분말 첨가 쿠키의 경도는 Table 6에 나타내었 다. 대조군의 경도는 $5,051.66 \mathrm{~g}$ 이며, 실험군의 경도는 $4,107.67-4,836.67 \mathrm{~g}$ 이었다. 대조군에 비해 양파껍질 분말 을 첨가하여 제조한 쿠키의 경도가 통계적으로 유의하게 감소하였다 $(\mathrm{p}<0.01)$. 양파껍질 분말을 $2 \%$ 첨가하여 제조 한 쿠키의 경도는 대조군과 통계적으로 유의성 있는 차이 를 나타내지 않았으나, 양파껍질 분말을 $4 \%$ 및 $6 \%$ 첨가하 여 제조한 쿠키에서는 대조군과 $2 \%$ 첨가군에 비해 경도가 감소하였다. 쿠키의 경도는 첨가하는 부재료의 특성 및 첨가비율, 기공의 발달, 수분함량 등에 따라 달라진다(Joo 와 Choi, 2012b). 세발나물 분말(Son 등, 2015), 연잎 분말 (Kim과 Park, 2008)을 첨가하여 제조한 쿠키에서는 이들 부재료의 첨가량이 증가함에 따라 경도가 증가한 반면, 김 분말(Lee 등, 2017), 벌나무잎 분말(Park 등, 2018), 모링 가잎 분말(Choi, 2018)을 첨가하여 제조한 쿠키에서는 부 재료의 첨가량이 증가할수록 경도가 감소하는 것으로 나
타나, 부재료의 종류에 따라 쿠키의 경도가 달라지는 것을 알 수 있다. 본 연구에서는 양파껍질 분말 첨가량이 증가 할수록 섬유소 함량이 증가하고, 식이섬유의 수분 보유력 으로 인해 쿠키의 수분함량이 증가하여 쿠키의 경도가 감소되었으며, 반죽 형성에 필요한 수분이 양파껍질과 결 합함으로써 글루텐 형성이 억제되어 쿠키조직이 연화된 것으로 사료된다.

\section{쿠키의 총 polyphenol 및 총 flavonoid 함량 분석}

양파껍질 분말 첨가 쿠키의 총 polyphenol 및 총 flavonoid 함량 분석결과는 Table 7과 같다. 양파껍질 분말을 첨가하 지 않은 쿠키의 총 polyphenol 함량은 $0.63 \mathrm{GAE} \mathrm{mg} / \mathrm{g}$ 이었 으나, 양파껍질 분말을 첨가한 쿠키의 총 polyphenol 함량 은 $1.13-2.01 \mathrm{GAE} \mathrm{mg} / \mathrm{g}$ 으로 양파껍질 분말의 첨가량이 증가할수록 총 polyphenol 함량은 유의적으로 증가하였다 $(\mathrm{p}<0.01)$.

Chung 등(2018)에 따르면 양파껍질 에탄올 추출물의 총 polyphenol 함량은 $69.23 \mathrm{GAE} \mathrm{mg} / \mathrm{g}$ 으로 보고되었는데, 본 연구에서 양파껍질 분말의 첨가량이 증가할수록 쿠키 의 polyphenol 함량이 증가한 것은 양파껍질 분말의 polyphenol 함량 때문인 것으로 판단된다. Chung 등(2018) 의 연구에서 보고된 양파껍질의 총 polyphenol 함량과 본 연구에서 양파껍질의 첨가비율을 고려했을 때, 쿠키의 총

Table 6. Texture properties of cookies with different amounts of onion peel powder

\begin{tabular}{l} 
Measurement \\
\cline { 2 - 4 }
\end{tabular}


Table 7. Antioxidant activities of cookies with different amounts of onion peel powder

\begin{tabular}{|c|c|c|c|c|c|}
\hline \multirow{2}{*}{ Measurement } & \multicolumn{4}{|c|}{ Group $^{1)}$} & \multirow{2}{*}{ F-value } \\
\hline & Control & OP2 & OP4 & OP6 & \\
\hline Total polyphenol $\left(\mathrm{mg} \mathrm{GAE}^{2} / \mathrm{g}\right)$ & $0.63 \pm 0.23^{4) \mathrm{b} 5)}$ & $1.13 \pm 0.32^{\mathrm{ab}}$ & $1.36 \pm 0.08^{\mathrm{ab}}$ & $2.01 \pm 0.47^{\mathrm{a}}$ & $9.79^{* * 6)}$ \\
\hline Total flavonoid (mg QE $\mathrm{QE}^{3} / \mathrm{g}$ ) & $0.11 \pm 0.02^{\mathrm{d}}$ & $0.43 \pm 0.03^{\mathrm{c}}$ & $0.57 \pm 0.03^{\mathrm{b}}$ & $0.68 \pm 0.08^{\mathrm{a}}$ & $76.17^{* * *}$ \\
\hline DPPH radical scavenging activity (\%) & $25.62 \pm 2.98^{\mathrm{c}}$ & $49.22 \pm 4.59^{b}$ & $61.85 \pm 2.07^{\mathrm{a}}$ & $63.80 \pm 3.23^{\mathrm{a}}$ & $82.59^{* * *}$ \\
\hline ABTS radical scavenging activity (\%) & $11.82 \pm 0.82^{\mathrm{d}}$ & $51.11 \pm 2.97^{\mathrm{c}}$ & $65.14 \pm 0.90^{\mathrm{b}}$ & $70.08 \pm 1.24^{\mathrm{a}}$ & $701.31^{* * *}$ \\
\hline
\end{tabular}

polyphenol 함량의 차이가 나는 이유는 쿠키의 베이킹 과 정에서 polyphenol 성분이 일부 파괴되었기 때문인 것으로 사료된다(Kim 등, 2018).

식품이나 생체 내에 활성산소가 존재하면 지방이나 생 체 내 세포막의 지질 성분은 유리기와 반응하여 산화되고, 이것은 식품의 품질 저하와 생체 노화의 원인이 된다. 이 러한 산화 반응을 억제하기 위해 polyphenol성 물질이 이 용되고 있다(Huang 등, 1992).

Polyphenol은 통곡물, 과일, 야채, 견과류에 많이 함유되 어 있는 생리활성 물질로 phenolic acid, flavonoid, stilbens, lignin 등 몇 개의 그룹으로 나눌 수 있다. 식품 중의 flavonoid 는 flavonols, flavones, flavanols, flavanones, isoflavones, proanthocyanins으로 구분할 수 있다(Gharras, 2009).

Flavonol의 일종인 quercetin은 발암물질의 생성을 억제 하거나 감소시키고, 간에서 형질 전환되는 것을 방해하여 암의 발생을 예방한다(Huang 등, 1992). 쿠키의 총 flavonoid 함량은 중량 $1 \mathrm{~g}$ 당 quercetin을 기준으로 대조군이 0.11 $\mathrm{mg} \mathrm{QE} / \mathrm{g}$ 이고, 양파껍질 분말을 첨가한 실험군에서는 0.43 - $0.68 \mathrm{mg} \mathrm{QE} / \mathrm{g}$ 으로 나타났다. 양파껍질 분말 첨가량이 증가할수록 총 flavonoid 함량이 유의적으로 증가하였다 $(\mathrm{p}<0.001)$. 이러한 결과는 양파껍질을 이용한 우육포에서 양파껍질 추출물의 첨가량이 증가할수록 총 polyphenol 및 총 flavonoid 함량이 증가한 연구결과와 유사한 경향을 보였다(Jung과 Sim, 2019).

\section{쿠키의 항산화 활성 측정}

쿠키의 DPPH 라디칼 소거능은 Table 7과 같다. 양파껍 질 분말을 첨가하지 않은 대조군의 $\mathrm{DPPH}$ 라디칼 소거능 이 $25.62 \%$ 인데 반해, 양파껍질 분말을 첨가한 쿠키에서는 $49.22-63.8 \%$ 의 소거 활성을 보였다. 양파껍질 분말의 첨 가량이 증가할수록 $\mathrm{DPPH}$ 라디칼 소거능도 유의적으로
증가하였다 $(\mathrm{p}<0.001)$. 자유라디칼의 일종인 $\mathrm{DPPH}$ 는 짙은 자색을 띠는데, phenolic compound에 의해 탈색되므로 이 러한 색 변화를 이용하여 항산화 활성을 평가할 수 있다 (Lee 등, 2005). 본 연구에서는 쿠키의 양파껍질 분말의 첨가량이 증가할수록 $\mathrm{DPPH}$ 라디칼 소거능이 증가하였고, 총 polyphenol 및 총 flavonoid 함량도 양파껍질 분말의 첨가량에 비례하여 증가하였다.

쿠키의 ABTS 라디칼 소거능은 Table 7과 같다. ABTS 라디칼 소거능은 대조군이 $11.82 \%$ 이었고, 양파껍질 분말 을 첨가한 실험군에서는 $51.11-70.08 \%$ 로 증가하였다. $\mathrm{DPPH}$ 라디칼 소거능과 마찬가지로 양파껍질 분말의 첨가 량이 증가할수록 $\mathrm{ABTS}$ 라디칼 소거능도 유의적으로 증가 하였다 $(\mathrm{p}<0.001)$. ABTS 라디칼은 peroxidase, $\mathrm{H}_{2} \mathrm{O}_{2}$ 와 반응 하여 $\mathrm{ABTS}^{+}$로 변화된 후 시료에 의해 $\mathrm{ABTS}^{+}$가 소거되면 서 청록색이 탈색된다(Wang 등, 1998). 이러한 탈색 정도 로 $\mathrm{ABTS}$ 라디칼 소거능을 측정하고, 항산화능을 측정할 수 있다. 본 연구에서 양파껍질 분말의 첨가량이 증가할수 록 $\mathrm{ABTS}$ 라디칼 소거능이 증가한 것은 양파껍질 분말에 함유되어 있는 다양한 flavonoid 및 phenolic compound에 의한 것으로 판단된다. 선행연구에서 쿠키에 건오디박의 첨가량이 증가할수록 총 polyphenol 함량이 증가하였고, $\mathrm{ABTS}$ 와 $\mathrm{DPPH}$ 라디칼 소거능이 함께 증가하는 것을 확인 하였다(Jeon 등, 2013).

\section{쿠키의 아크릴아마이드 함량 분석}

쿠키의 아크릴아마이드 함량은 Fig. 2 와 같다. 양파껍질 분말을 첨가하지 않은 대조군의 아크릴아마이드 함량은 $40.38 \mu \mathrm{g} / \mathrm{kg}$ 이었고, 양파껍질 분말을 첨가한 실험군의 아 크릴아마이드 함량은 $28.02-38.24 \mu \mathrm{g} / \mathrm{kg}$ 으로 나타났다. 아크릴아마이드의 함량은 양파껍질의 첨가량에 따라 감 소하는 경향을 보였다. 본 연구결과를 바탕으로 아크릴아 


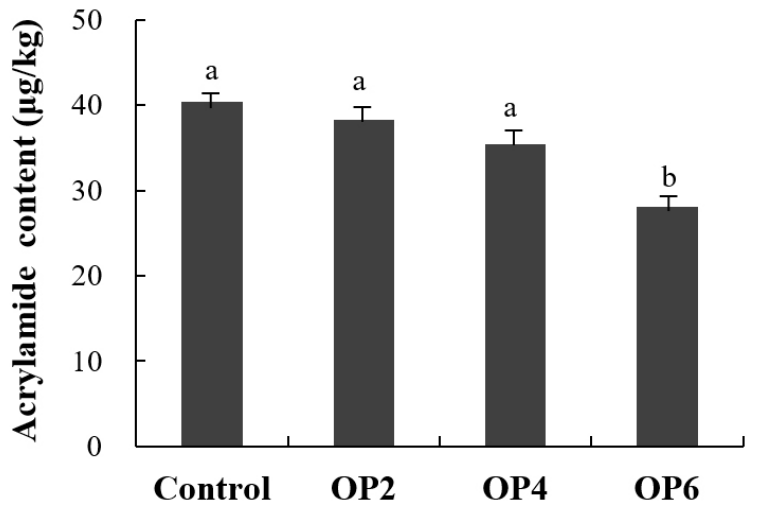

Fig. 2. Acrylamide content of cookies with different amounts of onion peel powder.

Control, no onion peel powder added; OP2, $2 \%$ onion peel powder added; OP $4,4 \%$ onion peel powder added; OP $6,6 \%$ onion peel powder added.

Different letters above the bars indicate significantly different at $\mathrm{p}<0.05$.

마이드의 생성을 낮추기 위해서는 최소한 $6 \%$ 이상의 양파 껍질을 첨가할 것을 권장한다 $(\mathrm{p}<0.05)$.

식품 중의 환원당은 유리 아스파라긴과 Maillard 반응에 관여하며, 유리된 아스파라긴의 아미노기 $\left(-\mathrm{NH}_{2}\right)$ 는 카르 보닐기 $(-\mathrm{CO})$ 와 만나면 아크릴아마이드를 생성하게 된다.

아크릴아마이드는 동물 실험 결과, 암, 신경계 이상, 생 식 기능 이상, 유전적 변이를 일으킨다고 알려져 있으며, 장기간 섭취하면 발암 가능성이 있는 물질로 분류되어 있다(IARC, 1994; Friedman 등, 1995). 이러한 아크릴아마 이드는 온도, 가열시간, $\mathrm{pH}$, 수분함량, 첨가물질에 의해 생성량이 달라지는데, 항산화 물질을 첨가하여 아크릴아 마이드 형성을 저감시키는 방법들도 시도되고 있다(Acar and Gokmen, 2009). 지금까지 보고된 연구결과에 의하면 vitamin C, polyphenol 화합물인 gallic acid, tannin, epicatechin, naringenin, ferulic acid, rutin, quercetin은 아크 릴아마이드 형성을 저감시키는 데에 효과적인 것으로 보 고되었다(Cheng 등, 2009; Jin 등, 2013; Ibrahim 등, 2016; Mildner 등, 2019). Mildner 등(2019)의 빵 껍질 모델연구에 서 $0.1 \%$ quercetin을 첨가한 경우, 아크릴아마이드 형성이 $30 \%$ 이상 저감되었으며, Ibrahim(2016)의 연구에서 감자 를 $200 \mathrm{ppm}$ 의 quercetin 용액에 1시간 침지 후 튀겼을 때 아크릴아마이드 형성이 억제되었다. 유럽연합의 조사결 과, 2016년 아크릴아마이드 함량은 감자칩의 경우 $500 \mathrm{ng} / \mathrm{g}$ 이하로 나타났으며, 이를 바탕으로 기준치가 $750 \mathrm{ng} / \mathrm{g}$ 으로 규정되었다(Powers 등, 2017). 본 연구에서 쿠키의 아크릴 아마이드 함량은 그 기준치보다 안전한 것으로 나타났다. 양파에는 ferulic acid, rutin, quercetin, gallic acid, kaempferol, tannic acid 등의 페놀성 화합물, allyl sulfide 및 allyl propyl disulfide와 같은 황화합물과 무기질, 식이섬
유가 다량 함유되어 있다. 이중 ferulic acid, gallic acid, quercetin, tannic aicd 등의 polyphenol 화합물은 껍질 쪽으 로 갈수록 함량이 큰 폭으로 증가한다(Fossen 등, 1998; Cheng 등, 2009; Cheng 등, 2013; Jin 등, 2013; Pino 등, 2015; Chia 등, 2018).

본 연구에서 양파껍질 첨가량이 증가할수록 아크릴아 마이드 함량이 감소한 것은 양파껍질에 함유된 quercetin을 비롯한 gallic acid, ferulic acid 등의 polyphenol 화합물이 아크릴아마이드 형성을 억제했기 때문인 것으로 사료된다.

\section{요 약}

본 연구에서는 양파껍질 분말을 2-6\% 첨가한 쿠키를 제조하여 품질 특성, 항산화 활성 및 아크릴아마이드 함 량을 측정하였다. 수분함량은 양파껍질 분말을 첨가하지 않은 대조군이 $2.95 \%$ 이었고, 양파껍질 분말을 첨가한 실 험군의 수분함량은 $3.13-3.43 \%$ 로 유의하게 증가하였다. 조회분은 양파껍질 분말의 첨가량이 증가할수록 유의하 게 증가하였으나, 조단백질은 양파껍질 분말을 첨가한 실험군에서 다소 감소하였다. $\mathrm{pH}$ 는 양파껍질 분말의 첨 가량이 증가할수록 유의하게 감소하였다. 퍼짐성은 대조 군이 가장 높았고, 손실률은 양파껍질 분말첨가량이 증가 할수록 감소하였다. 색도는 양파껍질 분말의 첨가량이 증가할수록 $\mathrm{L}$ 값, $\mathrm{b}$ 값은 감소하였고, $\mathrm{a}$ 값은 증가하였다. 경도는 양파껍질 분말을 첨가한 실험군에서 유의하게 감 소하였다. 양파껍질 분말의 첨가량이 증가할수록 총 polyphenol 함량, 총 flavonoid 함량, DPPH와 ABTS 라디칼 소거능이 증가하였다. 아크릴아마이드 함량은 양파껍질 분말을 2-4\% 첨가할 때는 대조군과 유의차가 없으므로 최소한 $6 \%$ 이상을 첨가할 것을 권장한다. 본 연구결과를 통해 양파껍질 중의 항산화 물질은 열에 안정적이어서 쿠키 중에 잔존할 수 있고, 그 결과 항산화 활성을 나타내 어 아크릴아마이드 형성을 감소시킨 것으로 사료된다. 따라서 양파껍질 분말을 쿠키에 첨가하는 것은 쿠키의 기능성 및 식품 안전성을 증진시켜 쿠키에 긍정적인 효과 를 줄 수 있을 것으로 판단된다. 본 연구결과는 양파의 부산물로 폐기 처분되는 양파껍질의 활용도를 더욱 높이 고, 이를 이용해 기능성 식품을 제조할 수 있는 기초 자료 를 제공할 것으로 사료된다.

\section{감사의 글}

본 연구는 한국연구재단 기본연구지원사업(과제번호 2019R1F1A1058764)의 지원에 의해 이루어진 것이며, 그 지원에 감사드립니다. 


\section{Conflict of interests}

The authors declare no potential conflict of interest.

\section{ORCID}

Mi-Sook Yeom https://orcid.org/0000-0003-2175-2255

Eun-Sun Hwang https://orcid.org/0000-0001-6920-3330

\section{References}

AACC. Approved Methods of the AACC. American Association of Cereal Chemists, St. Paul, MN, USA. Method p 10-50 (2000)

Acar OC, Gokmen V. Investigation of acrylamide formation on bakery products using a crust-like model. Mol Nutr Food Res, 53, 1521-1525 (2009)

Blois MS. Antioxidant determinations by the use of a stable free radical. Nature, 181, 1199-200 (1958)

Cheng A, Chen X, Jin Q, Wang W, Shi J, Liu Y. Comparison of phenolic content and antioxidant capacity of red and yellow onions. Czech J Food Sci, 31, 501-508 (2013)

Cheng KW, Zeng X, Tang YS, Wu JJ, Liu Z, Sze KH, Chy IK, Chen F, Wang M. Inhibitory mechanism of naringenin against carcinogenic acrylamide formation and nonenzymatic browning in Maillard model reactions. Chem Res Toxicol, 22, 1483-1489 (2009)

Chia PW, Lim BS, Tan KC, Yong FSJ, Kan SY. Water extract of onion peel for the synthesis of bisindolylmethanes. J King Saud Univ Sci, 31, 642-647 (2019)

Cho MR, Chung HJ. Quality characteristics and antioxidant activity of cookies made with black carrot powder. J Korean Soc Food Cult, 34, 612-619 (2019)

Choi HY. Antioxidant activity and quality characteristics of pine needle cookies. J Korean Soc Food Sci Nutr, 38, 1414-1421 (2009)

Choi JE, Lee JH. Quality and antioxidant attributes of cookies supplemented with cranberry powder. Korean J Food Sci Technol, 47, 132-135 (2015)

Choi SH. Quality characteristics and antioxidant activity of cookies added with moringa (Moringa oleifera Lam.) leaf powder. Culin Sci Hosp Res, 24, 102-111 (2018)

Chung YK, Choi JS, Yu SB, Choi YI. Physicochemical and storage characteristics of Hanwoo Tteokgalbi treated with onion skin powder and blackcurrant powder. Korean J food Sci Anim Resour, 38, 737-748 (2018)
FDA, US. Food \& Drug Administration. Detection and Quant itation of Acrylamide in Foods. https://www.fda.gov/food /chemicals/detection-and-quantitation-acrylamide-foods. (accessed Jan 2019)

Fossen T, Pedersen AT, Andersen OM. Flavonoids from red onion (Allium cepa). Phytochemistry, 47, 281-285 (1998)

Friedman MA, Dulak LH, Stedham MA. A lifetime oncogenicity study in rats with acrylamide. Fundam Appl Toxicol, 27, 95-105 (1995)

Gharras H El. Polyphenols: Food sources, properties and applications - A review, Int J Food Sci Technol, 44, 25122518 (2009)

Huang MT, Ferraro T. Phenolic compounds in food and cancer prevention. In: Phenolic Compounds in Food and Their Effects on Health II, American Chemical Society, p 2-8 (1992)

IARC. Monographs on the evaluation of carcinogenic risks to humans: Some industrial chemicals. Int Agency Res Cancer, 60, 389 (1994)

Ibrahim MAL, Mahgoub MA, Reham MAE, Abdel HMO, Alaa ELA. Reducing of acrylamide content in fried Egyptian foods using some natural compounds. J Drug Res Egypt, 37, 1-8 (2016)

Jaime L, Molla E, Fernandez A, Martin-Cabrejas MA, Lopez-Andreu FJ, Esteban RM. Structural carbohydrate differences and potential source of dietary fiber of onion (Allium cepa L.) tissues. J Agric Food Chem, 50, 122-128 (2002)

Jeon HL, Oh HL, Kim CR, Hwang MH, Kim HD, Lee SW, Kim MR. Antioxidant activities and quality characteristics of cookies supplemented with mulberry pomace. J Korean Soc Food Sci Nutr, 42, 234-243 (2013)

Jin $\mathrm{C}$, Wu X, Zhang Y. Relationship between antioxidants and acrylamide formation: A review. Food Res Int, 51, 611-620 (2013)

Joo SY, Choi HY. Antioxidant activity and quality characteristics of cookies with chestnut inner shell. Korean J Food Nutr, 25, 224-232 (2012a)

Joo SY, Choi HY. Antioxidant activity and quality characteristics of black rice bran cookies. J Korean Soc Food Sci Nutr, 41, 182-191 (2012b)

Jung EY, Sim KH. Antioxidant activities and quality characteristics of beef jerky supplement with onion peel extract. Korean J Food Nutr, 32, 11-26 (2019)

Jung KJ, Lee SJ. Quality characteristics of rice cookies prepared with sea mustard (Undaria pinnatifida Suringer) 
powder. J Korean Soc Food Sci Nutr, 40, 1453-1459 (2011)

Kim GS, Park GS. Quality characteristics of cookies prepared with lotus leaf powder. Korean J Food Cook Sci, 24, 398-404 (2008)

Kim SY, O H, Lee P, Kim YS. Quality characteristics, antioxidant activity and sensory properties of cookies added with freekeh powder. Culin Sci Hosp Res, 24, 18-29 (2018)

Ko EY, Nile SH, Sharma K, Li GH, Park SW. Effect of different exposed lights on quercetin and quercetin glucoside content in onion (Allium cepa $\mathrm{L}$.). Saudi J Biol Sci, 22, 398-403 (2015)

Korean Statistical Information Service. http://kosis.kr/statHtml /statHtml.do?orgId=101\&tblId=DT_1ET0291\&vw_cd= MT_ZTITLE\&list_id $=F 1 H \&$ seqNo $=\& l a n g \_$mode $=k o \&$ language $=$ kor\&obj_var_id $=\& \mathrm{itm} \_\mathrm{id}=\&$ conn_path $=\mathrm{MT}$ ZTITLE (accessed Nov 2019)

Lee JA, Song JS, Yoon JY. Quality characteristics of cookies with added dried laver (Porphyra tenera) powder. Culi Sci Hos Res, 23, 88-96 (2017)

Lee JO, Lee SA, Kim KH, Choi JJ, Yook HS. Quality characteristics of cookies added with hot-air dried yellow and red onion powder. J Korean Soc Food Sci Nutr, 37, 342-347 (2008)

Lee SO, Lee HJ, Yu MH, Im HG, Lee IS. Total polyphenol contents and antioxidant activities of methanol extracts from vegetables produced in Ullung island. Korean $\mathrm{J}$ Food Sci Technol, 37, 233-240 (2005)

Lee YS, Lim NY, Lee KH. A study on the preparation and evaluation of dried noodle products made from composite flours utilizing arrowroot starch. Korean J Food Cook Sci, 16, 681-688 (2000)

Lim JA, Lee JH. Quality and antioxidant properties of cookies supplemented with black sesame powder. J Korean Soc Food Sci Nutr, 44, 1058-1063 (2015)

Ma SH, Kim GW, Son JY. Quality characteristics and antioxidant effects of Makgeolli with onion skin by Nuruk and Ipguk. Korean J Food Cook Sci, 35, 288-298 (2019)

Mildner SS, Rozaaska M, Piechowska P, Waskiewicz A, Zawirska WR. Effects of polyphenols on volatile profile and acrylamide formation in a model wheat bread system. Food Chem, 297, 125008 (2019)

Mildner-Szkudlarz S, Zawirska-Wojtasiak R, Obuchowski W, Goslinski M. Evaluation of antioxidant activity of green tea extract and its effect on the biscuits lipid fraction oxidative stability. J Food Sci, 74, 362-370 (2009)

Nile SH, Nile AS, Keum YS, Sharma K. Utilization of quercetin and quercetin glycosides from onion (Allium cepa L.) solid waste as an antioxidant, urease and xanthine oxidase inhibitors. Food Chem, 235, 119-126 (2017)

Park BH, Cho HS, Park SY. A study on the antioxidative effect and quality characteristics of cookies made with Lycii fructus powder. Korean J Food Cook Sci, 21, 94-102 (2005)

Park H, Oyunzul G, Suh SW, Park YS, Jang JK, Chung MS, Choi YJ, Shim KS. Investigation of functional ingredients from onion according to the extraction methods, heat treatment, and storage period. Food Eng Prg, 13, 92-98 (2009)

Park SJ, Kim DH, Rha YA. The quality characteristics of cookies containing of Acer termentosum Maxim leaf powder. Culin Sci Hosp Res, 24, 120-126 (2018)

Pinho C, Soares MT, Almeida IF, Aguiar AARM, Mansilha C, Ferreira I. Impact of freezing on flavonoids/radicalscavenging activity of two onion varieties. Czech J Food Sci, 33, 340-345 (2015)

Powers SJ, Mottram DS, Curtis A, Halford NG. Acrylamide levels in potato crisps in Europe from 2002 to 2016. Food Addit Contam Part A, 34, 2085-2100 (2017)

Re R, Pellegrini N, Proteggente A, Pannala A, Yang M, Rice-Evans C. Antioxidant activity applying an improved ABTS radical cation decolorization assay. Free Radic Biol Med, 26, 1231-1237 (1999)

Reddy V, Urooj A, Kumar A. Evaluation of antioxidant activity of some plant extracts and their application in biscuits. Food Chem, 90, 317-321 (2005)

Salazar R, Arambula-Villa G, Vazquez-Landaverde PA, Hidalgo FJ, Zamora R. Mitigating effect of amaranth (Amarantus hypochondriacus) protein on acrylamide formation in foods. Food Chem, 135, 2293-2298 (2012)

Sayed HS, Hassan NMM, El MHA. The effect of using onion skin powder as a source of dietary fiber and antioxidants on properties of dried and fried noodles. Curr Sci J, 3, 468-475 (2014)

Sharma K, Assefa AD, Kim S, Ko EY, Lee ET, Park SW. Evaluation of total phenolics, flavonoids and antioxidant activity of 18 Korean onion cultivars: A comparative study. J Sci Food Agric, 94, 1521-1529 (2014)

Singleton VL, Rossi JA. Colorimetry of total phenolics with 
phosphomolybdic-phosphotungstic acid reagents. Am J Enol Vitic, 16, 144-158 (1965)

Slavin M, Lu Y, Kaplan N, Yu LL. Effects of baking on cyanidin-3-glucoside content and antioxidant properties of black and yellow soybean crackers. Food Chem, 141, 1166-1174 (2013)

Son EJ, Park SY, Kim MR. Antioxidant activities and quality characteristics of cookies added with aged black chestnut inner shell. Korean J Food Soc Food Sci Nutr, 46, 202-209 (2017)

Son HK, Kong HM, Cha SS, Choi YJ, Lee JJ. Quality characteristics of cookies added with Spergularia marina Griseb powder. Korean J Food Preserv, 22, 211-217 (2015)

Song JJ, Yang EI, Kim YS, Kim YS, Jeong YS. Quality production and characterization of functional fermented milk using onion peel extract. J Agric Life Sci, 55-59 (2013)

Sung WC, Chen CY. Influence of cookies formulation on the formation of acrylamide. J Food Nutr Res, 5, 370-378 (2017)
Vogrincic M, Timoracka M, Melichacova S, Vollmannova A, Kreft I. Degradation of rutin and polyphenols during the preparation of tartary buckwheat bread. J Agric Food Chem, 58, 4883-4887 (2010)

Wang M, Li J, Rangarajan M, Shao Y, Lavoie EJ, Huang TC, Ho CT. Antioxidative phenolic compounds from sage (Salvia officinalis). J Agric Food Chem, 46, 4869-4873 (1998)

Woisky RG, Salatino A. Analysis of propolis: Some parameters and procedures for chemical quality control. J Apic Res, 37, 99-105 (1998)

Zhang SL, Deng P, Chao XU Y, LU SW, Wang JJ. Quantification and analysis of anthocyanin and flavonoids compositions, and antioxidant activities in onions with three different colors. J Integr Agric, 15, 2175-2181 (2016)

Zhang Y, Chen J, Zhang X, Wu X, Zhang Y. Addition of antioxidant of bamboo leaves (AOB) effectively reduces acrylamide formation in potato crisps and French fries. J Agric Food Chem, 55, 523-528 (2007) 